\title{
Competence and Employee Innovative Behaviour in the Nigerian Telecommunication Industry
}

\author{
Jasmine Okponanabofa Tamunosiki-Amadi ${ }^{1} \&$ Bunatari Ogoun $^{1}$ \\ ${ }^{1}$ Faculty of Management Sciences, Niger Delta University, Bayelsa State, Nigeria \\ Correspondence: Jasmine Okponanabofa Tamunosiki-Amadi, Niger Delta University, Wilberforce Island, \\ Bayelsa State, Nigeria. E-mail: jassy.tammy@yahoo.com
}

Received: April 11, 2018

doi:10.5539/ijbm.v13n7p210
Accepted: May 18, 2018

Online Published: June 15, 2018

URL: https://doi.org/10.5539/ijbm.v13n7p210

\begin{abstract}
This study primarily examined the nature of relationship that exists between Competence a type of psychological empowerment and employee innovative behaviour. The study which was carried out in the telecommunication sector, operational in south-south region of Nigeria relied on the questionnaire as the primary instrument for generating data which was followed with observations. The study measured the innovative behaviour with measures like idea generation, idea development and idea implementation. Respondents were drawn from a sample size of 310 employees from the Telecommunication firms. The data generated were descriptively and inferentially analyzed. The descriptive analysis was done using means, standard deviations and percentages while the inferential analysis used the Spearman Rank Order Correlation Coefficient (rho) and regression analysis. From the analysis carried out, it was found that Competency had a significant weak association with idea generation and idea development but a positive significant relationship with idea implementation. Hence competence enhances employees' ideas generation, development and implementation of innovative behaviour.
\end{abstract}

Keywords: competence, idea generation, idea development, idea implementation, psychological empowerment

\section{Introduction}

There is no doubt an imposing challenge to critically find out workplace variables that stimulate desired performance especially in the case of multi environmental factors that influence goal attainment. Competitiveness amongst firms in same sector has assumed a wholesome dimension that requires only strategic action aimed at both building employee competencies and capability and environmental adaptations amidst others as proactive measures for continued survival and growth.

Employee empowerment may be perceived as a kind of management operation, in which information evolves in a form of shared vision, pellucid goals, that results in the outcome of work and the effect it has on all is based on shared capability with respect to training and work experience gained or capability acquired at the appropriate time to perform the job effectively (Chaturvedi, 2008). The cognition of competence regarding psychological empowerment applies to the self-efficacy peculiar to effort that has to do with the capability of an employee to carry out her work with the required lore and expertise (Spreitzer1995). Researchers argued that psychologically empowered people usually perceive themselves as fit and capable to affect their task and work setting meaningfully in a way such as; displaying initiatives, promoting proactive behaviour and independently working to encourage employees towards achieving work place goals (Sprietzer, 1995; Thomas \& Velthouse, 1990; Jasmine \& Tamunosiki 2015).

Innovation is profitable for several economic reasons. Innovativeness helps in perceiving things from novel, fresh point of view and discovering fresh and improved procedures, services or products. Innovation helps to boost efficiency and productivity (Mueller \& Slaw, 2005) coupled with building up a firm's durability and malleability when faced with an increasing stormy external environment. Innovation could be benignant when passing through organizational change (Amabile \& Perlow, 2002). More attention is laid on the innovative capabilities within firms (Shalley \& Gilson, 2004).

According to Knol and Van Linge (2008) Innovation is significant to firm's progression and its capability to make available ingenious solutions to burning challenges. The ability to attract and retain lofty achieving workers is more likely when firm's encourages employees in enforcing original and ingenious concepts (Faugier, 
2005). As competition skyrockets in the world of business, creativity and employees innovative tendencies have become a highly cherished resource (Kotter \& Schlesinger, 2008), and having knowledge about the employees who have higher degrees of innovative behaviour within an organization is valuable.

Studies have affirmed the value creating importance to immerse employees in work setting in a way they are seen as strategic stakeholders rather than treat worker as just factors of production. In this regard, according to Pardem and Deshen (2003) they are psychologically driven to be innovative. This perspective notwithstanding, there is a gap in literature owing to lack of scholarly efforts at displaying a relationship between innovativeness and some intrinsic-oriented variables within the employee.

In the private sector empowerment has been associated to ameliorated performance (Spreitzer, 1995; Lawler, Mohrman, \& Ledford, 1992; Neilson \& Pedersen, 2003; Kirkman \& Rosen, 1999). A significant causal pathway through which employees empowerment affects performance is amidst innovative behaviour that relates to the first-rate or excellent employees (Bowen \& Lawler, 1995; Thomas \& Velthouse, 1990; Kanter, 1983; Gore, 1993). Empowered employees ameliorate performance by quickly recovering from mistakes in the discharge of service, learning from those mistakes or errors and creating innovative propositions for redesigning procedures and products. However, failure to inspire such behaviour can immensely weaken the effectiveness of empowerment programs.

The link between empowerment and encouragement to innovate is highly significant in the public sector, where goal ambiguity, high degree of formalization and limitation on the capability to reward extrinsically may dampen or neutralise the effectiveness of empowerment agendas (Ramsey, 2009).

While researchers have examine the influence of intrinsic motivation on outcomes like task performance (Chen and Klimoski, 2003: Grant, 2008), work attitudes (Avolio, et al, 2004: Liden, Wayne, \& Sparrow, 2000), and organizational citizenship behaviours (Piccolo \& Colquitt, 2006), its significant to note that, most of these studies were based on western cultures and there is astonishingly little or no research evidence that directly assess the influence of competence a form of psychological empowerment on innovative behaviour in Nigerian telecommunication organizations. George (2004) argued that, research has not consistently supported the intuitively fascinating assumptions that intrinsic motivation is fundamental to innovation. This study is therefore embarked on to fill the gap in literature by examining the relationship between competence and employee innovative behaviour in the Nigerian Telecommunication Sector.

\section{Literature Review}

\subsection{Competence}

Since the 1980s researchers and theorists have been examining the concept of employee empowerment and its results simultaneously with the swift technological changes and corporate downsizing in the work environment due to economic down turns. For employees to successfully substatiate and nurture personal learning in the workplace Masuod, Gholan and Mahammed (2012) suggested that, employees should demonstrate a feeling of self-restrain with respect to their education and aims. When viewed from a broader perspective, such feeling of control is a prototype of Psychological empowerment in literature. Empowerment allows employees to create physical and psychological mastery that positively aid organizations (Brancato, 2003). Empowerment is one very important factor that empowers employees to apply knowledge and skills especially when faced with complex organizational situations.

Competence infers that employees trust they possess the requisite abilities and skills to adequately accomplish task satisfactorily (Mishra \& Spreitzer, 1998). Competence compared with self efficacy was portrayed as a belief of a person in her ability to effectively carry out work skilfully. However, in recent times, organizations are now giving importance to the worth of employees knowledge, inspiring and demanding that employees continually engage in learning to be abreast with current happenings in order to enhance their career (Masuod, Gholan, \& Mahammed 2012).

It is necessary for employees in organizations to work as a team in order to build competencies, strategies and resources to react with foresight to the economic challenges. This could only be achieved when employee's feels empowered psychologically. Mishra and Spreitzer (1998), argued that, employee's usually tends to shun and evade work activities they perceive surpasses their abilities and skills, but are quick to embrace and partake competently in activities they believe in their ability to successfully and efficiently handle. Therefore, it is clear that employees are receptive to empowerment. Bhatnagar (2005) states that the word "empowerment" may not be viewed by different organizations in the same light, even employees in the same organization may not perceive it in the same manner. However, several researches have focused on empowerment and its techniques, only a few studies have 
concentrated on psychological empowerment. Psychological empowerment basically centres on the individual's self-efficacy and shared power in the organizational structure and decision-making processes (Morrison, Jones and Fuller, 1997).

\subsection{Innovative Behaviour}

Over the last decade, the phrase innovation has increasingly become a buzz word. There is much talk by almost everyone on the importance of innovation, but surprisingly only a few actually knows what innovativeness means (Weberg, 2009). According to Rogers (2003), innovation is an idea, practice, or object that is perceived as new by an individual or other unit of adoption. Innovation pertains or deals with the production and enforcement of ideas. Innovation takes place when ideas are enforced in a department or organization (Amabile, 1996). Some scholars argued that the generation of an idea can be regarded as creativity in variance to innovation which has an innate application component, therefore, encompasses idea generation and idea implementation (Amabile, 1996). Researchers of innovation have come up with a significant foundation of research knowledge over so many decades ago (Anderson et al, 2004), in addition to the people, groups or teams, units and organizational variables that enhance or hamper innovation.

Going forward, it is pertinent to note that there is always a misconception or misunderstanding regarding innovation and creativity (Drazin \& Schoonhoeven, 1996; Dauw, 1969). Some scholars and practitioners use the terms interchangeably (Amabile, 1996), Some others, suggests that creativity has to do with the generation of ideas and innovation the implementation of ideas (West \& Farr, 1990) yet some are of the opinion that creativity is synonymous with the individual and innovation with the organizational level (Dauw, 1969; Oldham \& Cummings, 1996). However, the most recognized view states that creativity deals with idea origination; on the other hand, innovation includes idea origination as well as transformation of the ideas to reality (Kanter, 1983; Mumford \& Gustafson, 1988; Unsworth \& Clegg, 2001). Creativity is therefore seen as unit of the innovative procedures and will be regarded as such in the course of this research study.

One widely quoted definition of innovation includes "a product or response will be judged as creative to the extent that (a) it is both novel and appropriate, useful, correct or valuable response to the task at hand and (b) the task is heuristic rather than algorithmic" (Amabile, 2000). This definition unambiguously states the measure as the production of new and serviceable ideas. Nonetheless, this creates room for multiple challenges. One, this may not be generalised over all situations. Sprecher (2000) carried out a study in which only 18 out of 107 engineers that were asked to define creativity mentioned novelty compared to comprehensiveness which was mentioned 34 times. Novelty and usefulness can be said to be founded upon subjective judgement and therefore seen as domain and time specific. The extent of originality required is an argumentative matter (Amabile 2000, Nystrom 1979) lastly, the judgement of usefulness hinge on the referent. What is considered useful in one domain may be completely useless in another. Consequent upon this, the widely accepted view that innovation is defined by the production of new and useful ideas is problematic. Drazin et al (1999) also argued that this outcome based definition ignores the test of the innovative process. They offered a definition that is founded on the engagement in actions, regardless of the maximum effect. The researchers concur with their propositions, opined that, innovation is an act of participating in behaviours aimed at generating and implementing novel ideas, procedures, services and products irrespective of the ultimate favourable outcome of the new phenomenon.

Creativity can be defined as the generation of new or original idea (Amabile, 1993, Mumford \& Gustafson, 1998). Innovation is way broader and extends beyond creativity to entail the generation, adaptation and execution of new and serviceable notions (Scott \& Bruce, 1994). Innovative behaviour at work involves searching out novel ideas, developing and championing ideas, looking for funds and planning to implement the ideas. Such action involves increase pitfall and out-of-the-box thinking, its focus is decreased deference and apt with the status quo.

Innovative employees are constantly depicted as being self-sufficient, mutinous (Csikszentnihalyi, 1997) and challenging to contend with (Nickerson, 1999). Nontheless, to be recalcitrant against something you must study the regulations, the innovative person may be "traditional and conservative and also rebellious (Csikszentnihalyi, 1997). Innovative individuals are frank and perceptive to the surroundings and thereafter get more experience with excessive happiness and distress as well, and this leads to restlessness and uneasiness (Csikszentnihalyi, 1997). Gilbert, (2009) argued that sensitive and innovative employees are mindful of how of how their work is perceived and judged.

Employee innovative behaviour could contribute to competitive advantage of the organization therefore it is considered as one of the most significant aspect of organizational environment (Sosik et al, 1999). Redmond et al (1993) reported workplace innovation or innovative attitude of employees would add valuable items into organizational performance. 
Before going further, it is important to know at this point that there is much misunderstanding between creativity and Innovation (Drazin \& Schoonhoeven, 1996; Dauw, 1969). Most researchers use the words interchangeably (Amabile, 1996), Whereas others suggest creativity as the origination of ideas and innovation as the process of moving the ideas from conception to reality (West \& Farr, 1990). Yet people are confident that creativity is synonymous with personal level while innovation is associated with the firms or group level (Dauw, 1969; Oldham \& Cummings, 1996). However, the higly widely accepted perspective explains that creativity is concerned with begetting of ideas and the process of transforming the ideas from concepts to reality (Kanter, 1983; Mumford \& Gustafson, 1988; Unsworth \& Clegg, 2001). Creativity therefore refers to just a unit of the innovation process, hence it will be regarded as same everywhere in the duration of this research study.

Amongst the frequently used definition is as follows: "a product or response will be termed as creative to the point or length that (a) it is new and suitable, serviceable, or beneficial use, accurate or valued reaction to the goal or duty at hand. (b) The duty or task is heuristic rather than algorithmic, and strategic to solving problems" (Amabile, 2000). This meaning makes it unequivocal; the yardstick is the making of new and serviceable ideas. Nevertheless, this raises some problems. Foremost, it might not be generalizable across domains: Sprecher (2000) requested 107 engineers to explain originality and found that newness was noted by only 18 people (equated with comprehensiveness which was noted 34 times). Newness and usefulness are rooted on subjective judgments (Amabile, 2000), hence, is domain and time specific. The extent of newness required is a belligerent issue. Lastly, the judgment of usefulness hinges upon the referent. What is useful to one person may be damaging or useless to another. Hence, the broadly accepted view that innovation is explain by the making of new and serviceable results is problematic. In addition, Drazin et al (1999) suggested that this result based explanation disregards the test of the change process. They offer statement that is hinged on appointments in behaviours, in spite of the maximum output. The researcher agrees with their suppositions as well as suggests that innovation is the process of engaging in behaviours created to bring and carry out new ideas, process, products and services, irrespective of the maximum success of those new phenomena.

Creativity can be described as the production of new ideas (Amabile, 1983, Mumford \& Gustafson, 1988). Innovative behaviour goes beyond carrying out new and useful ideas (Scott \& Bruce, 1994). Innovative character at work encapsulates actions such as searching out new ideas, excellent ideas at work, as well as protecting funds/putting in place future causes of actions to carry out these ideas (Scott \& Bruce, 1994). This kind of behaviour demands more risk and out-of-the-box thinking it is less focused on compliance and fitting in with the status quo.

Whilst it has been recognized that organizational survival largely depends on the aptitude to innovate (Cally, 2005), the always changing dynamic business environment have no doubt accelerated the rapidity with which organizations will be asked to create new services and commodities offered in order for them to preserve and ameliorate their status (Searle \& Bell, 2003). One means for organizations to be increasingly innovative rests on their capacity to promote, create and support the skills, especially the innovative abilities of their workers (Amabile, 1988; Oldman \& Cummings, 1996; Searle \& Bell, 2003). Farooq et al (2018) acknowledged that leadership styles also positively influence innovative outcomes. The case for organizations then is how to stimulate workers capable of developing ideas to create, and how to formulate the conditions by which organizational groups can manifest their innovative ideas for organizational survival.

\subsection{Competence and Employee Innovative Behavior}

Competence otherwise referred to as self-efficacy is an individual's person's belief in her capabilities to carry out work with mastery (Gist, 1999). Competence is akin to agency personal conviction, personal expertise or her instrumentality (Bandura, 1989). Competence is of the notion that a person is conscious of his/her capability of thriving when carrying out a specific duty (Bandura, 1986). Conger and Kanungo's (2000) argument of psychological support in organizations examines the subtle variation of self-efficacy as well as skill, ability and qualification with respect to employees. Competence in the work environment has been described as the capability to carryout task skilfully when work is performed (Thomas \& Velthouse, 2000). Competence is synonymous with self-efficacy (Spreitzer, 1995; Spreitzer et al, 1997; Thomas and Velthouse, 2000). Researchers (Bandura \& Schunk, 2001; Gist, 2004) scholars argued that self propelled achievement at a given task accelerates self-efficacy and contentment.

Researchers further argued that competence or self-efficacy is affiliated to intrinsic motivation (Gist, 1987).

Ryan and Deci (2001) asserted that existing research shows that having a sense of competence and self-assurance with respect to valued goal is related to increased psychological empowerment and well-being. 
Mumford and Gustafson, (1988) Redmond et al, (1993), opined that feelings of self-efficacy results in greater innovativeness. Bass (1990) are of the view that workers with ameliorated self-efficacy are susceptible and often probable to produce new ideas with results. In the same vein, self-efficacy congruent with the competence dimension of empowerment is often probably to result in increased innovativeness as a result of favourable anticipation of the outcome (Amabile, 1988).

Empowerment produces a climate where employees feel productive, fulfilling a desire for self-actualization and accomplishment of employees. This atmosphere accelerates employee's self-respect and contentment (Robins et al., 2002). Having autonomy and choice to manage work, employees are most likely to have high self-efficacy, which will eventually facilitate and enhance employee innovative behaviour.

If employees are psychologically empowered their self-efficacy can be enhanced which could encourage employees for innovative behaviour (Tiemey et al., 1999). Employees' ability to develop new pattern for accomplishment of work and desirous to face more challenges, their novel attitude could develop innovative attitude among other members of the organization (Gardner \& Avolio, 1998). Employee innovative behaviour could be enhanced through intellectual stimulation and motivation (Mumford et al, 2002). Motivation would urge them to put more effort for problem solving and they are willing to involve themselves in innovative behaviour (Avolio and Pas, 1988). Therefore, when employees are empowered, they are at advantageous position owing to the fact that they may have superior self-efficacy, believing more in their personal ability and pride themselves to effectively and efficiently participate in the organization. According to Muzail Nagshbandi et al (2016) employees perceive a sense of self-esteem when they realise that they are part of the developmental process of knowledge and technology that leads to innovative outcomes. They are now appropriately motivated and well adjusted with the view of a more satisfaction considering there is a positive modification in their value orientation which may develop in an increasing innovative behaviour.

Individual competencies and capabilities achieved from work can raise the level of self esteem of the individual to produce or render a perfect or near perfect services to expand the horizon beyond what was originally assigned to them and experiment on things not done before. When employees discover competence in their work, there is an increased probability of them having the strength and encouragement to participate in jobs that are new, different, and upgraded. The strength which encompasses the right state of mind felt when one is zealous and able to participate in a well defined behaviour or carry out an assignment (Dutton, 2003; Quinn \& Dutton, 2005), is vital for moving above the expected duties and obligations to assimilate and work on new ideas. Although, previous studies had shown that negative affect or feeling of low self esteem can ignite innovative ideas or encourage and bring about better concepts (George \& Zhou, 2002; Kaufman \& Vosburg, 1997), updated research has analyzed these discoveries by revealing that it is the (sudden wake-up) or awakening associated with right feelings that illustrates the connection between the right feeling and creativity (Filipowitz, 2006). In addition, Kark and Carmeli (2009) have demonstrated that competence facilitates workers involvement in innovative work. Creative work is not inactive; it needs advancing and supporting ideas which takes energy. Innovative work is naturally an anticipatory kind of work behaviour (parker et al., 2006) where people search for new technologies, procedures, techniques, or even works related tendencies. Feeling competent and anxious to participate in innovative work behaviour is particularly critical in the light of the scepticism and opposition that innovators face from people who believe that the status quo is acceptable or even better (Dutton et al., 2001). In addition, it necessitates intrinsic motivational situations that empower workers to be committed in innovative behaviours. The foregoing attest theoretical variation on the level of association between the competence construct and innovative behaviour therefore, it is hypothesized as follows:

$H_{01}$ : There is no significant relationship between competence and idea generation.

$H_{02}$ : There is no significant relationship between competence and idea development

$H_{03}$ : There is no significant relationship between competence and idea implementation.

\section{Methodology}

Data was gathered from employees of the telecommunication sector in the South-South region of Nigeria. The cross sectional survey design was used. The research population is made up of employees in the telecommunication sector in Nigeria. We worked with employees in the telecommunication firms in the six state capitals of the South-South region as our accessible population. From the list of all the companies that are registered with the Nigerian Communication Commission (NCC), the researcher studied six telecommunication firms that are listed as primary service providers. The population figure was obtained from the telecommunication firm's nominal role. A total of one thousand five hundred and seventy-five employees made up the total population. The sample size for this study was determined using Krejcie and Morgan's (1970) 
sample size determination table. Our sample size was three hundred and ten employees. However when we distributed our questionnaire, the completed and usable copies for the analysis was 209 , representing $67.41 \%$ of respondents who genuinely participated in our study. The instrument used for data collection was the questionnaire and in-depth interview. The questionnaire was divided into two sections. Section A comprised of demographic information such as gender, educational qualifications and managerial level. Section B elicited respondent's views concerning the study variables. The questionnaire adopted the 5-point Likert Scale rating, where respondents were asked how strongly they agree or disagree with a statement or series of statement. The scale used for measuring competence was adapted from the work of Sprietzer (1995) and kirman and Rosen (1997). Employee Innovative Behaviour was measured using Bruce (2001) and Amabile (2002) Innovative Behaviour questionnaire (IBQ) which we adapted for our research. The IBQ measured idea Generation, Idea Development and Idea Implementation. The variables used for this research were sourced from existing literature and had been pre-tested and validated in previous studies (Spreitzer, 1995; Kirman and Rosen, 1997; Bruce, 2001; Amabile, 2002). Therefore the variables had construct validity. Cronbach Alpha was used to test for reliability in our study. Cronbach alpha is commonly used in research to test internal reliability. According to researchers (Bryman and Bell 2003; Nunally 1978; and Dana 2001) an alpha coefficient of 0.80 is generally accepted as a good level of internal reliability of the instrument, though an alpha level of 0.7 is also considered to be efficient. For test of reliability the following Cronbach Alpha Coefficients were obtained for our scales: Competence (0.775), Innovativeness (0.792). Hence all our variables had internal reliability.

Frequencies and percentages were used to classify our demographic data. Our variables were subjected to univariate and bivariate analysis. Inferential statistics using Spearman Rank Order Correlatcion Coefficient was used to establish the association between Competence and Employee Innovative behaviour.

\section{Data Analysis and Results}

Our demographic data was classified using frequencies and percentages.. The results from our demographic data shows that the minimum qualification of the respondents as proposed in the instrument is the NCE/OND and 47 (22.5\%) of the respondents have these level of qualification. The next which is HND/B.Sc/BA had 67 (32.1\%) of the respondents that were in those categories and the Masters degree level had 83 respondents which represents $39.7 \%$ of the sample. The highest of the qualification which is Ph.D had $12(5.7 \%)$ of the respondents at that level of qualification. 111 respondents were male employees in the telecommunication sector representing $53.1 \%$, while females constituted the remaining $46.9 \%$ and were 98 respondents. The first level management of the organizations has 111 respondents which represent $63.6 \%$ of the sample subjects. The middle level management had $51(24.4 \%)$ of the respondents that operates at that level and the top management level had 25 of the respondents which also represents $12 \%$ of sample. This shows that majority of the employees from the telecommunication sector in Nigeria were highly educated. We acquired the mean scores below for each variable using univariate analysis. Tables 1, 2, 3 and 4 gave the mean scores for each variable. Competence (COM) had four items on the scale; Employee Innovative Behaviour (EIB) had 9 items.

Our variables were subjected to univariate and bivariate analysis. Inferential statistics using Spearman Rank Order Correlation Coefficient was employed to confirm the association between Competence and Employee Innovative Behaviour.

Table1. Descriptive statistics of Competence

\begin{tabular}{llllll}
\hline & & COM 1 & COM 2 & COM 3 & COM4 \\
\hline $\mathrm{N}$ & Valid & 209 & 209 & 209 & 209 \\
Mean & Missing & 0 & 0 & 0 & 0 \\
Std Dev & & 2.91 & 3.00 & 2.97 & 3.23 \\
Skewness & & .502 & .000 & .167 & .425 \\
Std Error of skewness & -1.117 & -.91 & -.943 & -1.412 \\
Minimum & & .143 & .143 & .143 & .143 \\
Maximum & & & & & 0.00 \\
\hline
\end{tabular}

Source: Spss Computation. 
Table 2. Descriptive statistics of idea generation (employee innovative behaviour) survey

\begin{tabular}{llll}
\hline & & IG 1 & IG 2 \\
\hline $\mathrm{N}$ & Valid & 209 & 209 \\
& Missing & 0 & 0 \\
Mean & & 3.00 & 3.29 \\
Std Deviation & & 0.00 & .456 \\
Skewness & & -.320 & -.611 \\
Std Error of skewness & .143 & .143 \\
Minimum & & 0.00 & 0.00 \\
Maximum & & 4.00 & 4.00 \\
\hline
\end{tabular}

Source: Spss Computation.

Table 3. Descriptive statistics of idea development (employee innovative behaviour) survey

\begin{tabular}{llll}
\hline & & ID 1 & ID 2 \\
\hline $\mathrm{N}$ & Valid & 209 & 209 \\
& Missing & 0 & 0 \\
Mean & & 2.97 & 2.93 \\
Std Deviation & & .167 & .361 \\
Skewness & & -.424 & -.967 \\
Std Error of skewness & -.424 & -.967 \\
Minimum & & 0.00 & 0.00 \\
Maximum & & 4.00 & 4.00 \\
\hline
\end{tabular}

Source: Spss Computation.

Table 4. Descriptive statistics of idea implementation (employee innovative behaviour) survey

\begin{tabular}{|c|c|c|c|c|c|c|}
\hline & & IDI 1 & IDI 2 & IDI 3 & IDI 4 & IDI 5 \\
\hline \multirow[t]{2}{*}{$\mathrm{N}$} & Valid & 209 & 209 & 209 & 209 & 209 \\
\hline & Missing & 0 & 0 & 0 & 0 & 0 \\
\hline Mean & & 4.00 & 3.94 & 3.88 & 3.65 & 2.67 \\
\hline Std Dev & & 0.00 & .341 & .672 & .535 & 1.389 \\
\hline Skewness & & -1.982 & -.778 & .391 & -.914 & -1.146 \\
\hline Std Error of skewness & & .143 & .143 & .143 & .143 & .143 \\
\hline Minimum & & 0.00 & 0.00 & 0.00 & 0.00 & \\
\hline Maximum & & 4.00 & 4.00 & 4.00 & 4.00 & 4.00 \\
\hline
\end{tabular}

Source: Spss Computation.

Table 5. Association between competence and employee innovative behaviour

\begin{tabular}{llll}
\hline & $\mathrm{Ho}_{4}$ & $\mathrm{Ho}_{5}$ & $\mathrm{Ho}_{6}$ \\
& $\mathrm{C}(\mathrm{IG})$ & $\mathrm{C}(\mathrm{ID})$ & $\mathrm{C}(\mathrm{IM})$ \\
\cline { 2 - 4 } $\mathrm{N}$ & 209 & 209 & 209 \\
$\mathrm{Sig}(2$-tailed) & .000 & .000 & .000 \\
$\mathrm{Rho}$ & $.243^{* *}$ & $.318^{* *}$ & $.415^{* *}$ \\
\hline Note. ** Correlation is significant $@ 0.01$ Level (2-tailed).
\end{tabular}

From the results in the table above, competence as a dimension of psychological empowerment has positive and significant relationship with employee innovative behaviour. For competence and idea generation the relationship is very weak though significant. With $\mathrm{r}=0.243(\mathrm{p}<0.01)$ it shows the degree of association between them. The relationship between competence and idea development was also weak, but had positive and significant relationship with $\mathrm{r}$ values $=0.318(<0.10)$, but competence and idea implementation with $\mathrm{r}$ values $=$ $0.415(\mathrm{p}<0.01)$ was strong and significant. This simply means that the null hypotheses earlier stated are rejected which implies that a relationship exist significantly between competence and innovative behaviour though it is a weak type of association. 


\section{Discussion of Findings}

\subsection{Competence Strongly Relates with EIB}

The relationship between the competence component of psychological empowerment and innovative behaviour of employees in the telecommunication sector is obviously sublime. In other words, the relationship though positive, is weak but significant. On the other hand, our descriptive analytical outcome emphasized the competence dimension of psychological empowerment for the employees in the telecommunication sector. Competence is imperatively a requisite element that is needed for all work tasks. Quin and Spreiter (1997) espoused that competently empowered employees radiates a creative confidence that is required for tasks accomplishment. They look at old problems from new approaches and produce creative/innovative outcomes. What this connotes for the employee is that though there may exist other extrinsic work place incentives; there is high regard for the intrinsic cognitive capabilities that are endowed in the employee that enables him have a sense of belonging. Jung and Sokik (2002) concluded that the relevance of the agency relationship between the employer and the employee is owed to the skills inherent in the employee which are considered strategic for the entire production process. The issue of competence being important to employee creative capability has also been identified in the works of Hennessey and Grossman (2006). Their study correlated transformational leadership with innovativeness in work organization. They had further shown that transformational leadership creates an empowerment climate that is anchored on enhancing employee work skills as a pedestal for creativeness and innovative practices. The findings agree with Yang (2010) who noted that followers who feel competent develop strong confidence in self and they would actively develop their work competence and eagerly seek ways to improve their work and work conditions. According to Spreitzer (1995) they are more satisfied with their jobs and less likely to experience stress than those who do not feel competent.

Indeed, Conger and Kanungo (1995) are of the view that competence captures the idea that an individual feels capable of successfully performing a particular task or activity therefore a psychologically empowered workforce is that which is impliedly prepared with competitive skills that in the thinking of Bandura (1986) are stimulants of self-efficacy or personal mastery. The telecommunication sector from our findings has conformity with existing literature on the relationship between competence and an intrinsically motivated workforce. The need to create a creative climate in turn requires a competent workforce. There is a high sense of initiating an innovative work climate where according to Bandaru employees have the skills to confidently seek knowledge, process it and make novelty out of it. Moeller (2006) argued that the opportunity for creativity/innovativeness is the basis for deliberate employee motivation through skill enhancement strategies of organizations. Of course, skill enhancement programmes translate to eliciting extra work related behaviour which is essentially innovative in outcome. Our study result showed that in the telecommunication sector, there is a widespread concern for competence enhancement for the work force and this is borne out of the need to build capacity and stay innovative in the fast evolving sector with competitive tendencies.

We strongly believe from our study results that employees are bolder in attending to work tasks if they have a high competence profile that results from the extent to which empowerment is allowed. They are put at a point where they are quick at perceiving a link between their action and envisaged outcomes from their work input. There is an analogous position with extant literature on the crucial role of competence though this appears not to have been emphasized from the inferential outcome. This can however be explained when viewed in the light of the intrinsic nature of this factor which also require some extrinsic attempt to manifest or acquired (Shammy, 2003; Pettersberry, 2006). The extrinsic elements which we found in the study are the training for skill enhancement given to the employees of the telecommunication sector. In our personnel interview we found that ensuring a competent workforce through specialized and customized training programmes is a valued culture of the organization in the sector. These create a climate conducive for innovative behaviour which is built around idea generation, development and implementation.

\section{Conclusions and Implications}

\subsection{The Conclusions Drawn from the Study Are That}

1. The competence component of psychological empowerment showed significant in the study which reflects the fact that employees are mindful of the extent to which their acquired skills can make them remain at work and be seen to be helping them engendering work processes that facilitate organizational goals in the Telecommunication Industry.

2. The study through its finding has shown employee's knack for self confidence through acquired work skills in the Telecommunication Industry. 
3. Competence as acquired by the employees prepares them to generate, develop and implement ideas that assure goals attainment in the Telecommunication Industry.

This research study has theoretical implications as it confirms the findings of other studies. In the Nigerian Telecommunication Sector, Competency positively affects employee innovative behaviour. It also shows that employees who feel competent develops solid confidence of self and are most likely to anxiously search for ways to ameliorate their work skills and capabilities. We however suggest that capacity building and skill enhancement programmes should be considered strategic therefore, employees should be made to acquire and improve work skills that help them in the entire creative and innovative process of organizations. Continuous skill improvement programmes are needed for psycho-stability of the workforce as this will guarantee them their continued stay in the organization. Training and development could improve the competence position of individuals. Managers should expend time on wanting to understand people, setting targets, identifying development needs, facilitating personal development plans and giving positive and corrective feedback, employees' levels of self-efficacy will increase and they will experience that they make a difference in the workplace.

\section{References}

Amabile, T. M. (1983). The Social Psychology of Creativity: A Componential Conceptualization. Journal of Personality and Social Psychology, 45, 357-376. https://doi.org/10.1037/0022-3514.45.2.357

Amabile, T. M. (1988). A Model of Creativity and Innovation in Organizations. In B. M. Staw \& L. L. Cummins (Eds.), Research in Organizational Behavior (Vol. 10, pp. 123-167). Greenwich, CT: JAL Press.

Amabile, T. M. (1996). Creativity in Context: Update to "The Social Psychology of Creativity". Boulder Co: West view Press.

Amabile, T. M., \& Gitome, J. (2000). Children Artistic Creativity: Effects of Choice in Task Materials. Personality \& Social Psychology Bulletin, 10, 209-215. https://doi.org/10.1177/0146167284102006

Amabile, T. M.., Hadley, C. N., \& Kramer, S. J. (2002). Creativity under the Gun. Harvard Business Review, 80, 52-61.

Avolio, B. J., \& Bass, B. M. (1991). The Multifactor Leadership Questionnaire and Psychological Safety, Process Innovations, and Firm Performance.

Avolio, B.J., Zhu, W., Koh, W., \& Bhatia, P. (2004). Transformational Leadership and Organizational Commitment: Mediating role of psychological empowerment and moderating role of structural distance. Journal of Organizational Behavior, 25, 951-968. https://doi.org/10.1002/job.283

Bandura, A. (1997). Self-efficacy: The Exercise of Control. New York: W.H. Freeman.

Bandura, A., \& Schunk, D. H. (1981). Cultivating Competence, Self-efficacy, and Intrinsic Interest through Proximal Self-motivation. Journal of Personality and Social Psychology, 41(3), 586-598. https://doi.org/10.1037/0022-3514.41.3.586

Bass, B. (1990). From Transactional to Transformational Leadership: Learning to Share the Vision. Organizational Dynamic, 18, 19-31. https://doi.org/10.1016/0090-2616(90)90061-S

Bhatnagar, J. (2005). The Power of Psychological Empowerment as an Antecedent to Organizational Commitment in Indian Managers. Human Resource Development International, 8, 419-433. https://doi.org/10.1080/13678860500356101

Brancato, V. (2003). Enhancing Psychological Empowerment for Nurses. Pennsylvania Nurse, 58(4), 10.

Bryman, A., \& Bell, E. (2003). Business Research Methods. Oxford University Press.

Cally, B. (2005). The Climate for Service: An application of the climate construct. In B. Schneider (Ed.), Organizational Climate and Culture (pp. 382-412). San Francisco, CA: Jossey-Bass.

Chaturvedi, V. (2008): Employee Empowerment: A key to Intrinsic Motivation, Management Articles, Articles and papers by Faculty of Management Institutes.

Chen, G., \& Klimoski, R. J. (2003). The Impact of Expectations on Newcomer PERFORMANCE in teams as Mediated by Work Characteristics, Social Exchanges, and Empowerment. Academy of Management Journal, 46, 591-607.

Conger, J. A., \& Kanungo, R. N. (1988). The Empowerment Process: Integrating Theory and Practice. Academy of Management Review, 13(3), 471-482. https://doi.org/10.5465/amr.1988.4306983 
Csikszentmihalyi, M. (1996). Creativity: Flow and the Psychology of Discovery and Invention. NY: Harper Collins.

Dana, S. D. (2001). Statistics and Data Analysis for the Behavioural Sciences. New York: McGraw Hill Book Co.

Dauw, D. C. (1969). Bridging the Creativity Innovation Gap. The Journal of Creative Behaviour, 3(2), 84-89. https://doi.org/10.1002/j.2162-6057.1969.tb00048.x

Drazin, R., \& Schoonhoven C. B. (1996). Community, Population, and Organization Effects on Innovation: A Multilevel Perspective. The Academy of Management Journal, 39, 1065-1083.

Drazin, R., Glynn, M. A., \& Kazanjian, R. K. (1999). Multilevel Theorizing about Creativity in Organizations: A Sense Making Perspective. Academy of Management Review, 24, 286-307. https://doi.org/10.5465/amr.1999.1893937

Dutton, J. E. (2003). Breathing Life into Organizational Studies. Journal of Management Inquiry, 12, 1-19. https://doi.org/10.1177/1056492602250515

Dutton, J. E., \& Quinn, R. E. (2005). Positive Organizational Scholarship. San Francisco, CA: Berrett- Koehler.

Dutton, J. E., Ashford, S. J., O’Neill, R. M., \& Lawrence, K. A. (2001). Moves that Matter: Issue Selling and Organizational Change. Academy of Management Journal, 44, 716-736.

Farooq, A., Muzamil, M. N., Sharan, K., \& Boo, N. K. (2018). Roles of leadership styles and relationship-based employee governance in open service innovation: Evidence from Malaysian service sector. Leadership \& Organization Development Journal. https://doi.org/10.1108/LODJ-08-2017-0225

Faugier, J. (2005). Developing a New Generation of Nurse Entrepreneurs. Art \& Science, 19(30), 49-53.

Gardner, W. L., \& Avolio, B. A. (1998). The Charismatic Relationship: A Dramaturgical Perspective. Academy of Management Review, 23, 32-58. https://doi.org/10.5465/amr.1998.192958

George, J. M. (2007). Creativity in Organizations. Academy of Management Annals, 1, 439-477. https://doi.org/10.5465/078559814

George, J. M., \& Zhou, J. (2001). When Openness to Experience and Conscientiousness are Related to Creative Behaviour: An International Approach. Journal of Applied Psychology, 86, 513-524. https://doi.org/10.1037/0021-9010.86.3.513

Gilbert, C. (2003). The Competitive Advantages of Nations: The Role of HRM and its Socio-cultural Context. International Journal of Human Resources Management, September, 6(3), 157-166.

Gist, M. E. (1987). Self-efficacy: Implications for Organizational Behaviour and Human Resource Management. Academy of Management Review, 12(3), 472-485. https://doi.org/10.5465/amr.1987.4306562

Gist, M. E., \& Mitchell, T. R. (2002). Self-efficacy: A Theoretical Analysis of its Determinants and Malleability. Academy of Management Review, 17(2), 183-211. https://doi.org/10.5465/amr.1992.4279530

Grant, A. M. (2008). Does Intrinsic Motivation Fuel the Pro Social Fire? Motivational Synergy in Predicting Persistence, Performance and Productivity. Journal of Applied Psychology, 93, 48-58. https://doi.org/10.1037/0021-9010.93.1.48

Hennessey, F. J., \& Grossman, T. (2006). How Important are Job Attitudes? A Meta Analytic Comparison. Academy of Management Journal, 49, 305-325. https://doi.org/10.5465/amj.2006.20786077

Kanter, R. M. (1983). The Change Masters. New York: Simon and Schuster.

Kark, R., \& Carmeli, A. (2009). Alive and Creating: the Mediating Role of Vitality and Aliveness in the Relationship between Psychological Safety and Creative Work Involvement. Journal of Organizational Behaviour, 30(6), 785-804. https://doi.org/10.1002/job.571

Kirkman, B. L., \& Rosen, B. (1999). Beyond Self-Management: Antecedents and Consequences of Team Empowerment. Academy of Management Journal, 42, 58-74.

Knol, J., \& van Linge, R. (2008). Innovative Behaviour: the Effect of Structural and Psychological Empowerment on Nurses. Journal of Advanced Nursing, 65(2), 359-370. https://doi.org/10.1111/j.1365-2648.2008.04876.x

Kotter, J., \& Schlesinger, L. (2008). Choosing Strategies for Change. Harvard Business Review, 130-138. 
Krejcie, R. V., \& Morgan, D. W. (1970). Determining Sample SIZE for Research Activities. Educational and Psychological Measurement, 30, 601-610. https://doi.org/10.1177/001316447003000308

Liden, R. C., Wayne, S. J., \& Sparrowe, R. T. (2000). An Examination of the Mediating role of Psychological Empowerment on the Relations between the Job, Interpersonal Relationships, and Work Outcomes. Journal of Applied Psychology, 85(3), 407-416. https://doi.org/10.1037/0021-9010.85.3.407

Masuid, T. L, Gholan, A. S., \& Mahammed, S. (2012). The Examination of the Influences of Psychological Empowerment on Employee Innovative Behaviour in Social Security Organization of khorasanryzavi. Interdisciplinary Journal of Contemporary Research in Business, 4(8), 169-180.

Mishra, A. K., \& Spreitzer, G. M. (1998). Explaining how Survivors Respond to Downsizing: The Roles of Trust, Empowerment, Justice, and Work Redesign. Academy of Management Review, 22, 567-588. https://doi.org/10.5465/amr.1998.926627

Morrison, R. S., Jones, L., \& Fuller, B. (1997). The Relationship between Leadership Style and Empowerment on Job Satisfaction of Nurses. Journal of Nursing Administration, 27(5), 27-34. https://doi.org/10.1097/00005110-199705000-00007

Mueller, J. S., Melwani, S., \& Goncalo, J. A. (2011). The Bias against Creativity: Why People Desire but Reject Creative Ideas. Cornell University Articles \& Chapters, 450.

Mumford, M. D., \& Gustafson, S. B. (1988). Creativity Syndrome: Integration, Application and Innovation. Psychological Bulletin. 103(1), 27-43. https://doi.org/10.1037/0033-2909.103.1.27

Mumford, M. D., Scott, G. M., Gaddis, B., \& Strange, J. M. (2002). Leading Creative People: Orchestrating Expertise and Relationships. Leadership Quarterly, 13, 705-750. https://doi.org/10.1016/S1048-9843(02)00158-3

Muzamil, M. N., Sharan, K., \& PinMa, S. (2016). The Link between Organizational Citizenship behaviour and Open Innovation: A case of Malaysian High-tech sector. IJMB Management Review, 28(4), 200-211 https://doi.org/10.1016/j.iimb.2016.08.008Get rights and content

Nunnally, J. C. (1978). Psychometric Theory. New York, NY: McGraw-Hill, Inc.

Oldham, G. R., \& Cummings, A. (1996). Employee Creativity: Personal and Contextual Factors at Work. Academy of Management Journal, 39, 607-634.

Parker, S. K., Wall, T. D., \& Jackson, P. R. (2006). That's not my Job. Developing Flexible Employee Work Orientations. Academy of Management Journal, 40, 899-929.

Pettersbury, C. C. (2006). Promoting Integrating Approaches for Improving Psychological Empowerment. Journal of Behavioural Psychology, 11(2), 173-192.

Piccolo, R. F., \& Colquitt, J. A. (2006). Transformational Leadership and Job Behaviours: The Mediating Role of CORE Job Characteristics. Academy of Management Journal, 49, 327-340. https://doi.org/10.5465/amj.2006.20786079

Quinn, R. E., \& Spreitzer, G. M. (1997). The Road to Empowerment: Seven Questions every Leader should Consider. Organizational Dynamics, 26(2), 3 7-49. https://doi.org/10.1016/S0090-2616(97)90004-8

Redmond, M. R., Mumford, M. D., \& Teach, R. (1993). Putting Creativity to Work: Effects of Leader Behaviour on Subordinate Creativity. Organizational Behaviour and Human Decision Processes, 55, 120-151. https://doi.org/10.1006/obhd.1993.1027

Rogers, E. M. (2003). Diffusion of Innovations (5th ed.). New York: Free Press.

Ryan, R.M., \& Deci, E.L. (2001). On Happiness and Human Potentials: A Review of Research on Hedonic and Eudemonic well-being. Annual Review of Psych ology, 52, 141-166. https://doi.org/10.1146/annurev.psych.52.1.141

Scott, S. G., \& Bruce, R. A. (1994). Determinants of Innovative Behaviour: A Path Model of Individual Innovation in the Workplace. Academy of Management Journal, 37, 580-607.

Searl, K., \& Bell, C. D. (2003). Becoming an Employer of Choice: Assessing Commitment in the Hospitality Workplace. International Journal of Contemporary Hospitality Management, 8(6), 3-9.

Shalley, C. E., \& Gilson, L. L. (2004). What Leaders need to know: A Review of Social and Contextual Factors that can Foster or Hinder Creativity. The Leadership Quarterly, 15(1), 33-53. https://doi.org/10.1016/j.leaqua.2003.12.004 
Sharmy, G. (2003). Job Choice Decisions and Organizational Entry. Journal of Organizational Behaviour, 4(6), 332-348.

Sokik, A. L. (2002). Self Efficacy and Work Related Performance in Automobile Firms. Psychological Review, 10(6), 290-309.

Sosik, J. J., Kahai, S. S., \& Avolio, B. J. (1999). Leadership Style, Anonymity and Creativity in Group Decision Support Systems. Journal of Creative Behaviour, 33, 227-257. https://doi.org/10.1002/j.2162-6057.1999.tb01405.x

Sprecher, T. B. (2000). A Study of Engineers' Criteria for Creativity. Journal of Applied Psychology, 43(2), 141-148. https://doi.org/10.1037/h0047763

Spreitzer, G. M. (1995). Psychological Empowerment in the Workplace: Dimensions, Measurement and Validation. Academy of Management Journal, 38, 1442-1465.

Spreitzer, G. M. (1995). Psychological Empowerment in the Workplace: Dimensions, Measurement and Validation. Academy of Management Journal, 38, 1442-1465.

Spreitzer, G. M., Kizilos, M. A., \& Nason, S. W. (1997). A Dimensional Analysis of the Relationship between Psychological Empowerment and Effectiveness, Satisfaction, and Strain. Journal of Management, 23(5), 679-704.

Tamunosiki-Amadi, J. O., \& Dede, T. L. (2015). Self-determination and Employee Innovative Behaviour. European Journal of Business and Management, 35(7), 97-105.

Thomas, K. W., \& Velthouse, B. A. (1990). Cognitive Elements of Empowerment: An 'Interpretive' Model of Intrinsic Task Motivation. The Academy of Management Review, 15, 666-681.

Thomas, K. W., \& Velthouse, B. A., (2000). Cognitive Elements of Empowerment. Academy of Management Review, 5(4), 666-681.

Tierny, P., \& Farmer, S. M. (2002). Creative Self-efficacy: Its Potential Antecedents and Relationship to Creative Performance. Academy of Management Journal, 45, 1137-1148.

Unsworth, K. L. (2001). Unpacking Creativity. Academy of Management Review, 26(2), 286-297. https://doi.org/10.5465/amr.2001.4378025

Weberg, D. (2009). Innovation in Healthcare: A Concept Analysis. Nursing Administration Quarterly, 33(3), 227-237. https://doi.org/10.1097/NAQ.0b013e3181accaf5

West, M. A., \& Farr, J. L. (1989). Innovation at Work: Psychological Perspective. Social Behavior, 4, 15-30.

Yang, D. (2010). The Business Value of Emotions Management. Journal of Business Psychology.

\section{Copyrights}

Copyright for this article is retained by the author(s), with first publication rights granted to the journal.

This is an open-access article distributed under the terms and conditions of the Creative Commons Attribution license (http://creativecommons.org/licenses/by/4.0/). 